\title{
The effect of trypsin inhibitors \\ on pancreatopeptidase E, trypsin, chymotrypsin and amylase in the pancreas and intestinal tract of chicks receiving raw and heated soya-bean diets*
}

\author{
By A. GERTLER \\ Department of Agricultural Biochemistry and Animal Nutrition, \\ Faculty of Agriculture, Hebrew University, Rehovot, Israel \\ AND ZAFRIRA NITSAN \\ Division of Poultry Husbandry, The Volcani Institute of \\ Agricultural Research, Rehovot, Israel \\ (Received 9 October 1969-Accepted 24 June 1970)
}

\begin{abstract}
1. Feeding on a raw soya-bean diet (RSD) increased the levels of trypsin, chymotrypsin and pancreatopeptidase $\mathrm{E}$ but decreased the level of amylase in the pancreas of chicks as compared to a heated soya-bean diet (HSD), while supplementation of HSD with soya-bean trypsin inhibitors increased the activity of all four enzymes. HSD + trypsin inhibitors caused significant enlargement of the pancreas but only a slight depression in growth rate.

2. Fasting for $24 \mathrm{~h}$ of chicks previously given RSD and HSD increased the activity of all four enzymes but the increase was much greater in chicks previously given RSD than in those previously given $\mathrm{HSD}$.

3. Feeding RSD for $4 \mathrm{~d}$ to chicks previously adapted to HSD resulted in a dramatic inhibi tion in growth rate, a small increase in pancreas weight, and an increase in the activity of all proteolytic enzymes, while no change in the amylase was detectable.

4. Trypsin, chymotrypsin and pancreatopeptidase $E$ activities were assayed in the contents of the small intestine and caecum of chicks fed on RSD or HSD over a period of $35 \mathrm{~d}$. Trypsin and chymotrypsin activities in the small intestine were lower in chicks fed on RSD while pancreatopeptidase $\mathrm{E}$ activity was almost equal or even higher in RSD-fed chicks, especially at the age of $35 \mathrm{~d}$. Trypsin activity in the caecum of RSD-fed chicks was lower at all stages of the experiment, while the pancreatopeptidase $E$ and chymotrypsin activities in the caecum of RSD-fed chicks exceeded the levels in the HSD group at the age of 21 and $35 \mathrm{~d}$ respectively. It would appear therefore that pancreatopeptidase $\mathrm{E}$ may play an important part in overcoming the inhibition of the proteolytic activity in the intestine of chicks fed on RSD.
\end{abstract}

Raw soya-bean diets (RSD) cause growth inhibition and pancreas enlargement when used as a source of protein for animals (for review see Liener, 1969). Various investigators have attributed these phenomena to the presence of heat-labile trypsin inhibitors in RSD (Ham, Sandstedt \& Mussehl, r945; Westfall, Bosshardt \& Barnes, 1948), whereas others could not find a clear correlation between the presence of the latter in the diet and growth depression (Rackis, Smith, Nash, Robbins \& Booth, 1963; Saxena, Jensen \& McGinnis, 1963). Gertler, Birk \& Bondi (1967) found that addition of pure trypsin inhibitors to the diet of chicks and rats resulted in slight depression of growth but caused a significant enlargement of the pancreas.

The ratio between different enzymes in the pancreas is influenced by the composi-

* Contribution from the National and University Institute of Agriculture, Rehovot, Israel, I969 series, No. ${ }_{5} 8_{3} \mathrm{E}$. 
tion of the diet: protein-rich and carbohydrate-rich diets result in higher levels of proteolytic and amylolytic enzymes respectively (Howard \& Yudkin, 1963; MarchisMouren, Paséro \& Desnuelle, 1963 ; Reboud, Ben Abdeljlil \& Desnuelle, 1962). RSD increases the contents of proteolytic enzymes and decreases the content of amylase in the pancreas of chicks (Chernick, Lepkovsky \& Chaikoff, I948; Lepkovsky, Koike, Sugiura, Dimick \& Furuta, I966) and rats (Konijn, Guggenheim \& Birk, I969). Feeding with RSD causes also a significant reduction of the total proteolytic activity in the small intestine, whereas in the caecum either no change or an increase is noted (Alumot, \& Nitsan, r96r; Nitsan \& Alumot, 1963).

The aim of the work now described was to investigate the effect of soya-bean trypsin inhibitors upon proteolytic and amylolytic enzymes in the pancreas and intestinal tract of chicks, given heated or raw soya-bean meal. The effect of fasting for $24 \mathrm{~h}$ was also investigated. The four enzymes whose activities were studied were: $\alpha$-amylase

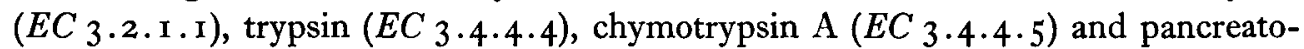
peptidase $E(E C 3.4 .4 \cdot 7)$. The last three are responsible for the endopeptidase activity of the pancreas, which is the main contributor to protein digestion. Particular consideration was given to examination of the activity of pancreatopeptidase $\mathrm{E}$ and the influence of the two diets on this enzyme, since very little is known about its role in protein digestion in birds and mammals.

\section{EXPERIMENTAL}

\section{Diets}

The percentage composition of the experimental diets was: heated (HSD) or raw (RSD) soya-bean meal ( $44 \%$ protein) 50 , glucose $20 \cdot 6$, potato starch $20 \cdot 6$, dicalcium phosphate $\mathbf{I} \cdot 5$, calcium carbonate, $\mathbf{r} \cdot 5$, vitamin mixture (Hurwitz \& Bornstein, $\mathbf{1 9}^{6} \mathbf{6}_{3}$ ) 0.12 , choline chloride $(50 \%) 0.2$, mineral mixture (Alumot \& Nitsan, I96I) 0.5 , soya-bean oil 5 .

Raw soya-bean meal was prepared by milling commercial soya-bean flakes defatted with light petroleum. Properly heated soya-bean meal was a commercial product. Trypsin and chymotrypsin inhibitor (AA) from soya-bean was prepared according to Birk \& Gertler (I 968), but the last step (of rechromatography) was omitted. The specific activity of the inhibitor was $8 \cdot 0$ trypsin-inhibiting and 10.2 chymotrypsin-inhibiting units/mg (Kunitz, 1947). Crystalline soya-bean trypsin inhibitor (CSBTI) (Kunitz, 1947) was a commercial product (Worthington Biochemical Corp. Freehold, NJ USA) with $3 \cdot 2$ trypsin-inhibiting and $0 \cdot 6$ chymotrypsin-inhibiting units $/ \mathrm{mg}$.

\section{Determination of enzymic activities}

Trypsin and chymotrypsin activities were estimated titrimetrically with benzoylL-arginine ethylester hydrochloride (BAEE) and $N$-acetyl-L-tyrosine ethylester (ATEE), respectively, as substrates (Neurath \& Schwert, I950). The BAEE and ATEE were obtained from Mann Research Laboratories, New York. The reaction was followed with Radiometer $\mathrm{pH}$-stat with automatic titrator II and one unit of activity was defined as one $\mu$ mole substrate hydrolysed/min at $25^{\circ}$. 
Pancreatopeptidase E activity was assayed by the Congo-red elastin method as described by Naughton \& Sanger (I961) and modified by Gertler \& Birk (1970). One unit was defined as the reciprocal of the time required to attain $50 \%$ digestion of Congo-red elastin measured in min and multiplied by 100. The specific activity of pure porcine pancreatopeptidase $\mathrm{E}$ was $200 \mathrm{units} / \mathrm{mg}$.

Amylase activity was estimated by the method of Bernfeld (1955), but the reaction was carried out at $37^{\circ}$ instead of $20^{\circ}$. The amylase unit was defined as an increase in I $\times \mathrm{IO}^{2}$ of extinction at $55^{\circ} \mathrm{nm}$ within $3 \mathrm{~min}$, using $\mathrm{I} \cdot 27 \mathrm{~cm}$ Spectronic 20 Bausch \& Lomb test-tubes.

For the determination of proteolytic enzymes in the pancreases, the latter were homogenized with 20 volumes of cold distilled water and centrifuged at $70000 \mathrm{~g}$ for $20 \mathrm{~min}$. The activation was carried out by mixing equal volumes of pancreas supernatant fraction and $\mathrm{I} \%$ enterokinase and incubating for $\mathrm{I} h$ at $37^{\circ}$ according to Gorill \& Thomas (1967). The purified enterokinase (Nutritional Biochemical Co., Cleveland, Ohio) was prepared in $\circ \cdot \mathrm{I}$ M-tris- $\mathrm{HCl}$ buffer (tris-hydroxymethyl amino methane),

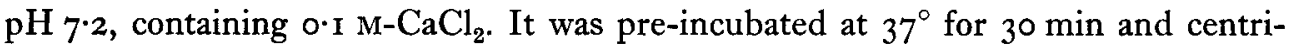
fuged at $2000 \mathrm{~g}$ to remove solid material.

The chyme of the jejunum, ileum and caecum was homogenized with 4 volumes of cold distilled water. The homogenates were centrifuged at $70000 \mathrm{~g}$ for $15 \mathrm{~min}$ and then tested for trypsin, chymotrypsin and pancreatopeptidase E. The proteolytic enzymes in the chyme were determined only when the chicks were fed.

\section{Experimental procedure}

Expt $\mathrm{x}$. New Hampshire $\times$ White Leghorn male chicks, $\mathrm{I} d$ old, were divided into two equal groups of fifty and given HSD and RSD from the ist day. At the age of 7 , $2 \mathrm{I}$ and $35 \mathrm{~d}$, sixteen chicks from each group were removed from their cages in the morning. Eight chicks from each group were put in a cage with water but no feed for $24 \mathrm{~h}$, after which time they were killed (fasted chicks). The remaining eight chicks from each group were killed immediately after the end of the experimental period (fed chicks).

After the chicks had been killed, the pancreases were removed, cleaned of extraneous material, weighed, and frozen at $-20^{\circ}$. The pancreases were kept frozen until assayed for proteolytic and amylolytic enzymes. The chyme of the jejunum, ileum and caecum was collected, weighed and analysed for proteolytic enzymes on the same day. The growth rate was also recorded throughout the experiment.

Expt 2. Three equal groups, each of ten I-d-old chicks, were fed as follows: group I were given HSD from hatching until the end of the experiment ( $32 \mathrm{~d})$; group 2 were given HSD from hatching until $28 \mathrm{~d}$ of age, and then RSD for $4 \mathrm{~d}$; group 3 were given RSD from the beginning to the end of the experiment. The chicks were treated and tested in the same way as the fasted chicks in Expt I.

Expt 3. Four equal groups, each of ten chicks, were given the following diets from hatching until $7 \mathrm{~d}$ of age: HSD, HSD + AA, HSD +CSBTI and RSD. The inhibitors were added to the HSD at a level of $0.3 \%(\mathrm{w} / \mathrm{w})$ of the diet. The chicks were killed 
after $24 \mathrm{~h}$ fasting; their pancreases were treated and tested for the same enzymic activities as in Expt $\mathrm{I}$.

The results of Expt I were analysed statistically by factorial analysis of variance; for Expts 2 and 3 the multiple range test was used (Snedecor, 1962).

\section{RESULTS}

\section{Expt I}

Feeding on RSD resulted, as expected, in pancreas enlargement and reduced growth rate as compared to chicks given HSD (Tables I-3). The maximal enlargement of the pancreas was observed after 2I d, confirming previous results (Alumot \& Nitsan, 1961). The effect of RSD and HSD on enzymic activities was very much dependent on the feeding state. During fasting, the level of all enzymes tested increased, particularly in the RSD group. The effect of RSD and HSD on the activity of the four enzymes/g pancreas was found to differ markedly between amylase on the one hand and the three proteolytic enzymes on the other. The amylase activity in chicks given RSD was equal to that in the controls (HSD) at the age of $7 \mathrm{~d}$, and lower at $2 \mathrm{r}$ and $35 \mathrm{~d}$. The difference increased with age, particularly in fed chicks. No constant trend was observed in the fasted chicks, probably because the increase in the enzymic activities during fasting was always much higher in the RSD group than in the control group.

The effects of the diet and feeding state on trypsin, chymotrypsin and pancreatopeptidase $\mathrm{E}$ were similar although not identical and the levels of these enzymes were in most instances higher in the RSD-fed than in the HSD-fed chicks. However, this general difference was very dependent on the feeding state. While the activities after fasting were always significantly higher in the RSD than in the HSD chicks, the differences in the fed birds were small and generally not statistically significant. The differences between the two diets were seen after $7 \mathrm{~d}$, which showed that the effect of RSD was rapid, and these differences became even larger with time. In most instances, and especially at the ages of 7 and $35 \mathrm{~d}$, significant interactions were found between the diet and the feeding state. In all these instances the significance of the main effects has no meaning and therefore the effect of fasting was calculated for each diet. In all instances, fasting resulted in statistically significant increases in enzymic activities in chicks given RSD, while in chicks given HSD the effect was small and mostly not significant.

In most instances calculation of the activities/100 g body-weight showed similar effects, but it changed the magnitude of the differences in enzymic activities caused by the diets, particularly at the ages of $2 \mathrm{I}$ and $35 \mathrm{~d}$, because the RSD-fed chicks had enlarged pancreases and lower body-weights. Thus, all the effects caused by RSD were emphasized. When the amylase activities were calculated/100 g body-weight, significant differences for the fed chicks were observed only at $2 \mathrm{I}$ d of age, at which the chicks given the RSD showed the higher activity. After fasting, the birds on the RSD treatment had significantly higher pancreatic amylase activity at all ages. 
Vol. 24

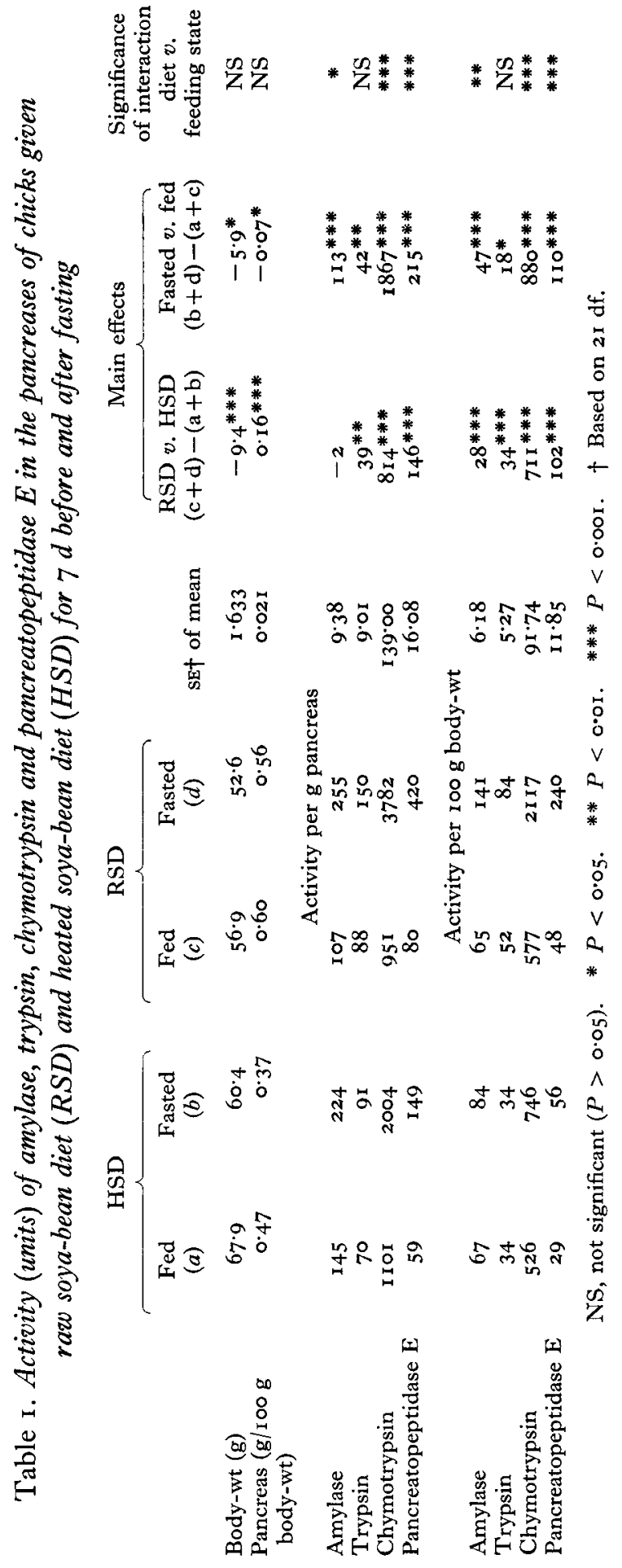







Vol. 24

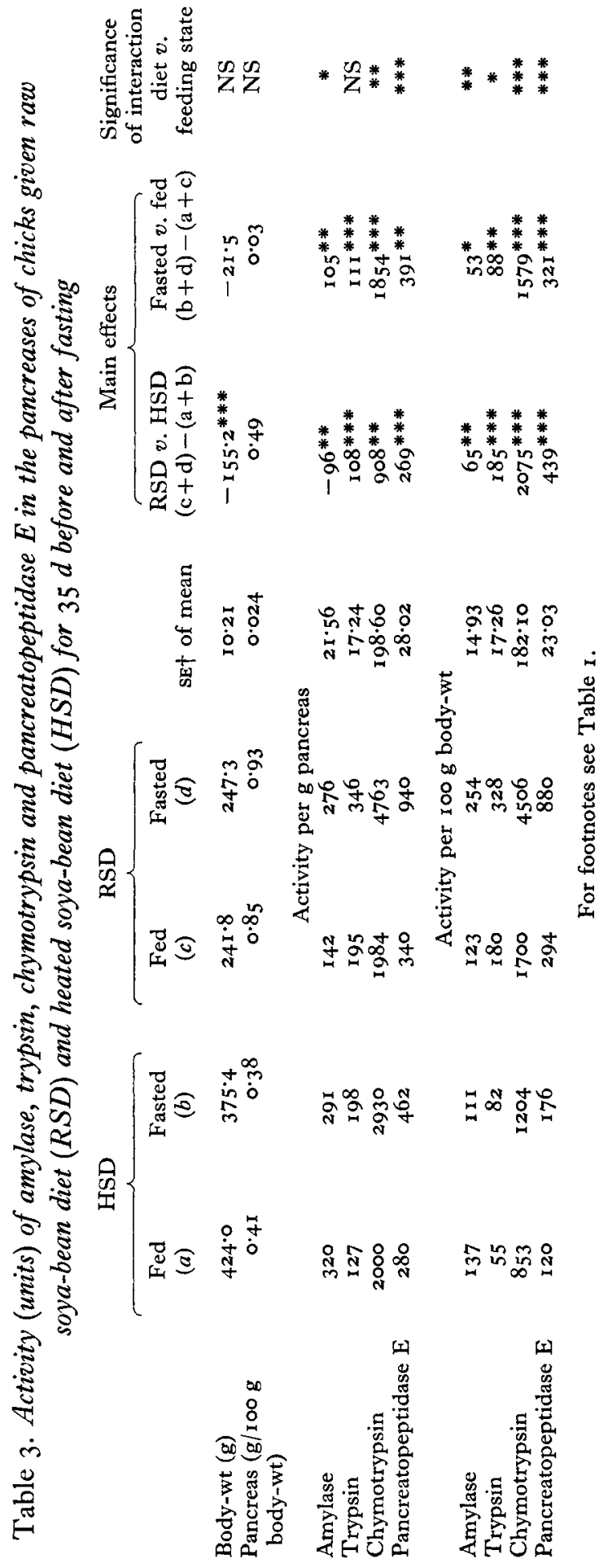


Calculations based on the activity on specific substrates compared with pure porcine pancreatopeptidase $E$ and bovine trypsin and chymotrypsin show that the fresh pancreases of RSD-fed chicks after $24 \mathrm{~h}$ of fasting contained $0.2-0.5 \%$ of pancreatopeptidase E, $0.3-0.7 \%$ of trypsin and $\mathrm{I} \cdot 0-\mathrm{I} \cdot 2 \%$ of chymotrypsin, compared with $0.08-0.23 \%$ of pancreatopeptidase E, $0.2-0.4 \%$ of trypsin and $0.4-0.8 \%$ of chymotrypsin for the HSD-fed chicks.



Fig. I. The activity of trypsin, chymotrypsin and pancreatopeptidase $\mathrm{E}$ per $\mathrm{g}$ chyme (left) and in the total amount of chyme (right) in the jejunum, ileum and caecum at 1,3 and 5 weeks of age. 패, HSD-fed chicks; $\square$, RSD-fed chicks. Each column represents the mean result for eight chicks. HSD, heated soya-bean diet; RSD, raw soya-bean diet.

Fig. I summarizes the activities of proteolytic enzymes in the jejunum, ileum and caecum and shows that the trypsin and chymotrypsin activities in both parts of the small intestine were higher at all ages in chicks given HSD. The pancreatopeptidase $\mathrm{E}$ activity tended to increase with age, especially in the RSD-fed chicks. At the age of $7 \mathrm{~d}$ the total activity of pancreatopeptidase $E$ was higher in the jejunum and ileum of the chicks given the HSD than in those given the RSD, as for the two other enzymes, but at the age of 5 weeks the pancreatopeptidase $E$ activity was higher in RSD-fed chicks in both parts of the small intestine. The trypsin and chymotrypsin activities were much higher in the caecum than in the small intestine on both diets: the tryptic activity was higher on the HSD at all ages, while the chymotrypsin and pancreatopeptidase $\mathrm{E}$ 
activities were higher on this diet only at the age of $7 \mathrm{~d}$ and at later ages decreased markedly, and no pancreatopeptidase $E$ activity could be detected at the age of 5 weeks, while in the RSD-fed group the pancreatopeptidase $\mathrm{E}$ activity in the caecum was very high.

\section{Expt 2}

In Expt I it was found that RSD increased the amount of proteolytic enzymes in the pancreas of chicks given RSD from hatching, and this experiment was designed to test the effect of transferring chicks previously given HSD to RSD after $28 \mathrm{~d}$. The results are presented in Table 4. The initial weight of HSD-fed chicks was much higher than that of the RSD-fed chicks. The transfer of 28-d-old chicks from HSD to RSD resulted in a dramatic decrease in growth rate even when compared with that of chicks given RSD throughout. The enlargement of the pancreas was rather small and statistically not significant. However, the $4 \mathrm{~d}$ of feeding on RSD were sufficient to cause an increase in specific activity of all three of the proteolytic enzymes, while the amylolytic activity was not affected.

When the results were calculated per roog body-weight, similar effects were obtained. Although the relative differences between different diets were the same, they were not statistically significant because of greater variability within the treatments.

\section{Expt 3}

The aim of this experiment was to investigate whether the effects of feeding with RSD, found in previous trials, were caused by the natural trypsin inhibitors present. The results obtained by supplementing the HSD with trypsin inhibitors (Table 5) confirmed the previously published findings (Gertler et al. 1967) that showed significant pancreas enlargement but only a slight effect upon growth rate. Trypsin inhibitors, and especially the trypsin inhibitor AA, increased the activities of all four enzymes, while the RSD increased only the proteolytic enzymes (see also Tables I-3). It should be remembered that both inhibitors were added on the same weight basis but the specific inhibiting activity of AA against trypsin was $2 \cdot 5$ and against chymotrypsin 15 times greater than that of CSBTI.

Both types of calculation gave similar results. This was as expected since at the age of $7 \mathrm{~d}$ the differences in the weight of pancreas expressed as a percentage of body weight were still relatively small.

\section{DISCUSSION}

The results of Expt 3 confirmed that addition of pure trypsin inhibitors to HSD hardly interfered with body growth but caused an enlargement of the pancreas (Gertler et al. 1967), and showed that this enlargement was accompanied by an increase of the amounts of proteolytic and amylolytic enzymes in the pancreas determined after $24 \mathrm{~h}$ of fasting. On the other hand, as shown in Expts I and 2, feeding RSD or transferring chicks from HSD to RSD resulted in an increase of proteolytic enzymes only, while the level of amylase was either not influenced or even decreased.

The mechanism by which trypsin inhibitors cause enlargement of the pancreas 
902

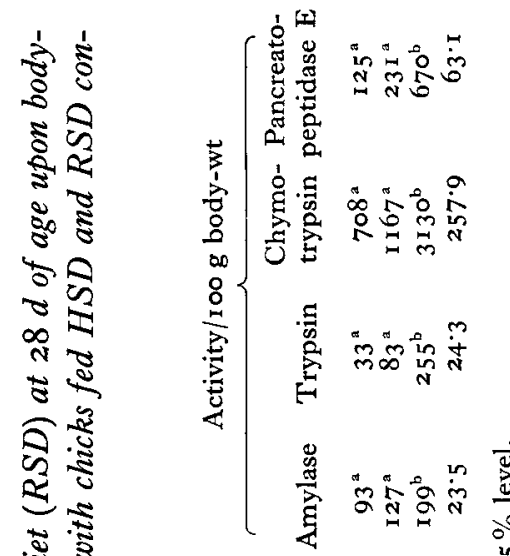

\&

รัँ है

डे

胥

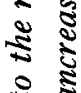

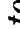

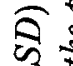

I.

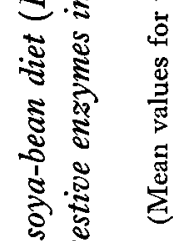

จ

छे

है है

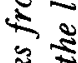

ฐ

.ำ 놀

s.



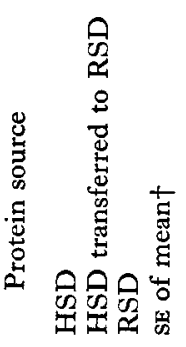

A. Gertler and Z. Nitsan

I 970

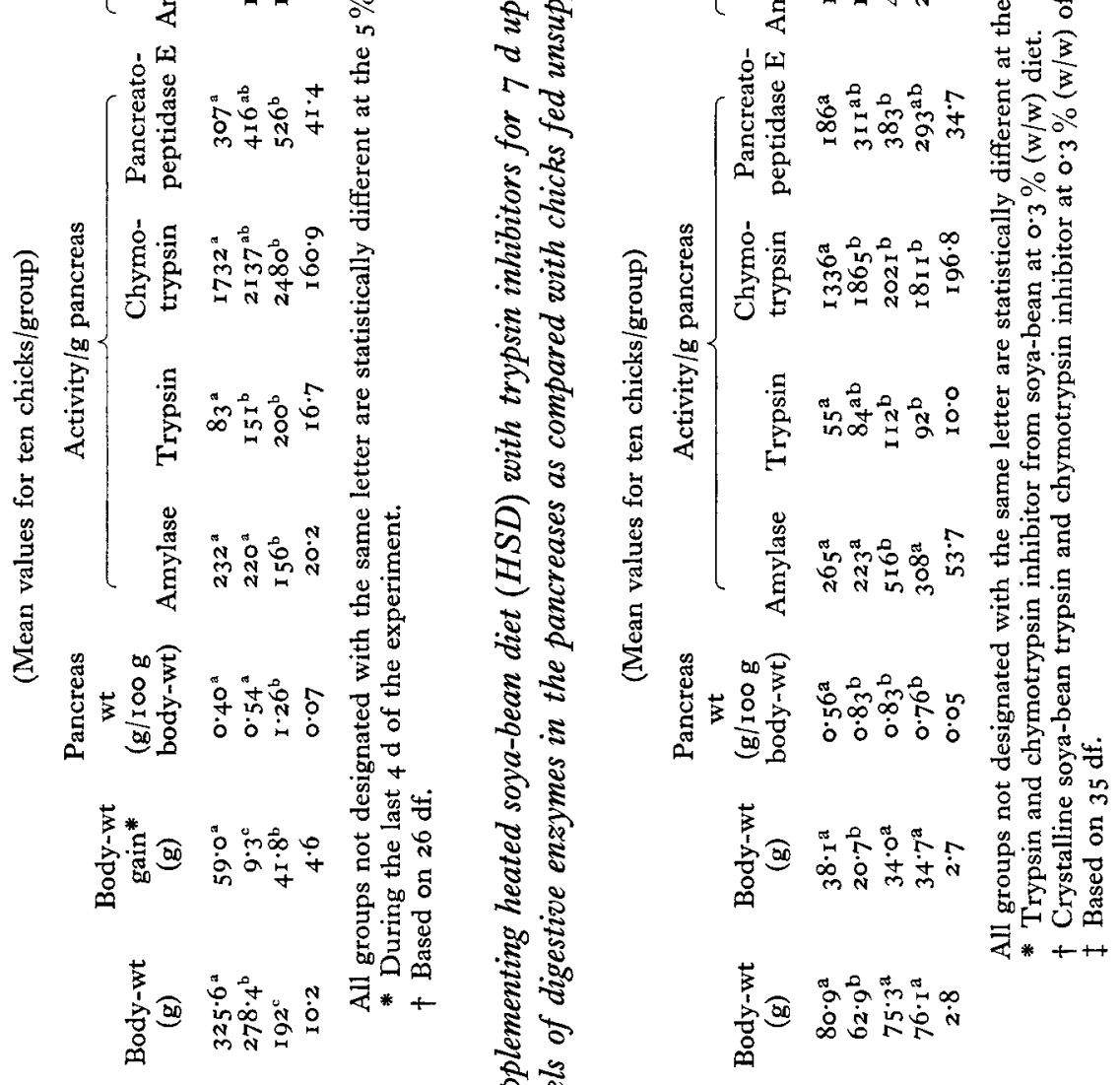



हे ह

ฐ)

ธี

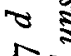

क

की

:

.

$\leqslant$ 용

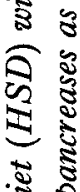

है क

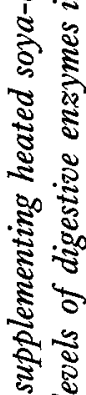

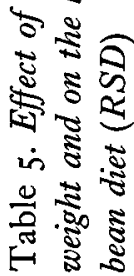



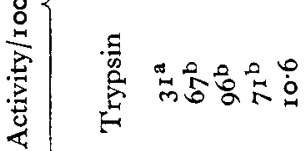

荡



离这

要。 웅

응 o.

. . 응

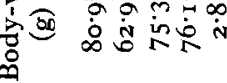

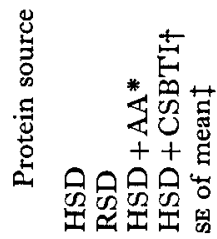


and increase the biosynthesis of proteolytic and amylolytic enzymes has not yet been clarified but, in experiments with rats, it has been shown that it includes production or secretion, or both, of one or more humoral factors. This factor (or factors) evidently acts by stimulating secretion of pancreatic enzymes (Khayambashi \& Lyman, 1966, 1969) rather than by stimulating the parasympathetic or vagal nervous system (Lyman, Wilcox \& Monsen, 1962). The chemical nature of this humoral factor(s) has not yet been established.

In view of these findings, the different effects on the amounts of proteolytic and amylolytic enzymes present in the pancreas, as found in Expts I-3, may be explained in the following way: trypsin inhibitors when added to HSD or in RSD always cause production or secretion of a humoral factor that stimulates the enlargement of the pancreas and increases biosynthesis of both proteolytic and amylolytic enzymes. However, with RSD the lower availability of amino acids, and the more serious deficiency of methionine, could limit the biosynthesis of amylase. The findings of Konijn \& Guggenheim ( 1967 ) that the pancreas of RSD-fed rats contained only $19 \%$ as much methionine as that of HSD-fed rats, and those of Lepkovsky, Koike et al. (1966) that supplementation of RSD with methionine increased the level of amylase in pancreases of chicks, support this hypothesis.

The effect of RSD and HSD, given for $35 \mathrm{~d}$, on the intestinal proteolytic activity (Fig. I) confirm, in general, the results previously reported (Alumot $\&$ Nitsan, I96r) that RSD caused a marked inhibition of the total proteolysis in the small intestine which was overcome in the course of the chicks' growth (Nitsan \& Alumot, I964). In the present investigation, in which the three main proteolytic activities were measured individually, it can be seen that in the beginning all three proteolytic enzymes were inhibited, and that the overcoming of the inhibition with age was mainly attributable to the pancreatopeptidase E. Since pancreatopeptidase $E$ is not inhibited by trypsin inhibitors (Gertler, unpublished results), it seems therefore that, although the pancreas of chicks given RSD produced increased amounts of both trypsin, chymotrypsin and pancreatopeptidase E, only the first two were bound by trypsin inhibitors from RSD, while the pancreatopeptidase $E$ was free. On the other hand, the specificity of pancreatopeptidase $\mathrm{E}$ is quite different from that of trypsin and chymotrypsin (Naughton \& Sanger, 196I; Sampath Narayanan \& Anwar, 1969). It is possible therefore that pancreatopeptidase $\mathrm{E}$ plays an important part in protein digestion, especially when trypsin and chymotrypsin are inhibited, as in RSD-fed chicks.

In the caecum, the activities of the proteolytic enzymes were higher when the HSD was given only in the ist week. Later on the activities of chymotrypsin and pancreatopeptidase $\mathrm{E}$ were lower in the control than in the RSD-fed group while trypsin activity was still higher in the HSD-fed chicks.

The possibility that some of the pancreatopeptidase $\mathrm{E}$ as well as trypsin and chymotrypsin in the small intestine, and especially in the caecum, may be of microbial origin should be considered. However, Lepkovsky, Furuta, Ozone, Koike \& Wagner (1966) showed that there was very little difference between the concentrations of trypsin and chymotrypsin in the intestinal contents of germ-free and of conventional rats, and Reddy, Pleasants \& Wostmann (1969) showed that the levels of these 
enzymes were even higher in germ-free rats. It seems reasonable to assume that the fate of pancreatopeptidase $\mathrm{E}$ in the intestinal tract is likely to be similar to that of trypsin and chymotrypsin and that the increased amount of pancreatopeptidase $E$ in the intestinal tract of chicks given RSD is therefore of pancreatic origin.

We thank Professor Yehudith Birk and Professor A. Bondi for their interest in the work and helpful suggestions, and gratefully acknowledge the technical assistance of Mrs Z. Zoref.

\section{REFERENCES}

Alumot, E. \& Nitsan, Z. (1961). F. Nutr. 73, 71.

Bernfeld, P. (1955). Meth. Enzym. r, 149.

Birk, Y. \& Gertler, A. (1968). Biochem. Prep. 12, 25.

Chernick, S. S., Lepkovsky, S. \& Chaikoff, I. L. (1948). Am. F. Physiol. 155, 33.

Gertler, A. \& Birk, Y. (1970). Europ. F. Biochem. 12, 170.

Gertler, A., Birk, Y. \& Bondi, A. (1967). F. Nutr. 9r, 358.

Gorrill, A. D. L. \& Thomas, J. W. (1967). Analyt. Biochem. 19, 211.

Ham, W. E., Sandstedt, R. M. \& Mussehl, F. E. (1945). F. biol. Chem. 161, 635.

Howard, F. \& Yudkin, J. (1963). Br. F. Nutr. 17, 281.

Hurwitz, S. \& Bornstein, S. (1963). Israel F. agric. Res. 13, I 47.

Khayambashi, H. \& Lyman, R. L. (1966). Fedn Proc. Fedn Am. Socs exp. Biol. 25, 676.

Khayambashi, H. \& Lyman, R. L. (I969). Am. F. Physiol. 217, 646.

Konijn, A. M. \& Guggenheim, K. (1967). Proc. Soc. exp. Biol. Med. 126, 65.

Konijn, A. M., Guggenheim, K. \& Birk, Y. (1969). F. Nutr. 97, 265.

Kunitz, M. (1947). Э. gen. Physiol. 30, 291.

Lepkovsky, S., Furuta, F., Ozone, K., Koike, T. \& Wagner, M. (1966). Br. F. Nutr. $20,257$.

Lepkovsky, S., Koike, T., Sugiura, M., Dimick, M. K. \& Furuta, F. (rg66). Br. F. Nutr. 20, 42 r.

Liener, I. E. (1969). In Toxic Constituents of Plant Foodstuffs p. 3 I. [1. E. Liener, editor]. New York and London: Academic Press.

Lyman, R. L., Wilcox, S. S. \& Monsen, E. R. (1962). Am. F. Physiol, 202, ro77.

Marchis-Mouren, G., Paséro, L. \& Desnuelle, P. (1963). Biochem. biophys. Res. Commun. $13,262$.

Naughton, M. A. \& Sanger, F. (I961). Biochem. F. 78, r 56.

Neurath, H. \& Schwert, G. W. (1950). Chem. Rev. 46, 69.

Nitsan, Z. \& Alumot, E. (1963). F. Nutr. 8o, 299.

Nitsan, Z. \& Alumot, E. (1964). F. Nutr. 84, I79.

Rackis, J. J., Smith, A. K., Nash, A. M., Robbins, D. J. \& Booth, A. N. (1963). Cereal Chem. 40, 53 r.

Reboud, J. P., Ben Abdeljlil, A. \& Desnuelle, P. (1 962). Biochim. biophys. Acta 58, 326.

Reddy, B. S., Pleasants, J. R. \& Wostmann, B. S. (1969). F. Nutr. 97, 327.

Sampath Narayanan, A. \& Anwar, R. A. (I969). Biochem. F. Ir4, II.

Saxena, H. C., Jensen, L. S. \& McGinnis, J. (1963). Proc. Soc. exp. Biol. Med. 112, Iог.

Snedecor, G. W. (1962). Statistical Methods 5 th ed. Ames, Iowa: The Iowa State College Press.

Westfall, R. J., Bosshardt, D. K. \& Barnes, R. H. (1948). Proc. Soc. exp. Biol. Med. 68, 498. 